\title{
PENANGANAN ASAM URAT DENGAN LATIHAN SENAM ERGONOMIK PADA LANSIA DI KELURAHAN GAHARU KECAMATAN MEDAN TIMUR
}

\author{
Masri Saragih ${ }^{1}$, Rumondang Gultom ${ }^{2}$, Rosetty Sipayung ${ }^{3)}$ \\ Universitas Sari Mutiara Indonesia ${ }^{1)}$ \\ Universitas Sari Mutiara Indonesia ${ }^{2)}$ \\ Universitas Sari Mutiara Indonesia ${ }^{3)}$ \\ masri_saragih@ymail.com
}

\begin{abstract}
ABSTRAK
Kadar asam urat yang tinggi dapat menyebabkan rasa nyeri pada tulang dan sendi, sering dialami oleh sebagian besar lansia. Dapat mengakibatkan lansia kesulitan untuk melakukan aktivitas akibat nyeri yang ditimbulkan. Pengobatan non farmakologis dapat dilakukan untuk mengontrol kadar asam urat yaitu dengan melakukan senam ergonomik. Senam ergonomik merupakan suatu gerakan otot yang dikombinasikan dengan teknik pernapasan. Tujuan dari Program Pengabdian masyarakat ini adalah untuk meningkatkan pengetahuan lansia dalam penanganan asam urat dengan latihan senam ergonomik. Metode kegiatan yang dilakukan adalah dengan penyampaian materi dan melakukan latihan senam ergonomik serta diskusi dan Tanya jawab. Hasil pelaksanaan kegiatan pengabdian ini setelah dilakukan penyuluhan dan latihan senam ergonomik menunjukkan 75\% paham terkait penjelasan materi dan $75 \%$ lansia dapat mempraktekkan latihan senam ergonomik.
\end{abstract}

Kata Kunci: Senam Ergonomik, Asam Urat, Lansia

\section{ABSTRACT}

High uric acid levels can cause pain in bones and joints, which is often experienced by most of the elderly. It can make it difficult for the elderly to do activities due to the pain they cause. Nonpharmacological treatment can be done to control uric acid levels by doing ergonomic exercise. Ergonomic exercise is a muscle movement combined with breathing techniques. The purpose of this Community Service Program is to increase the knowledge of the elderly in handling gout with ergonomic exercise. The method of activities carried out is by delivering material and doing ergonomic exercise as well as discussion and question and answer. The results of the implementation of this service activity after counseling and ergonomic exercise showed that $75 \%$ understood the material explanation and $75 \%$ of the elderly could practice ergonomic gymnastics exercises.

Keywords: Ergonomic Gymnastics, Gout, Elderly

\section{PENDAHULUAN}

Asam urat dihasilkan oleh setiap makhluk hidup sebagai hasil dari proses metabolisme sel yang berfungsi untuk memelihara kelangsungan hidup. Tubuh menyediakan 85 persen senyawa purin untuk kebutuhan setiap hari, hal ini berarti bahwa kebutuhan purin dari makanan hanya sekitar 15 persen (Yenrina, 2014). Makanan yang mengandung zat purin yang tinggi akan diubah menjadi asam urat. Hiperurikemia dapat membentuk kristal asam urat/ batu ginjal yang akan membentuk sumbatan pada ureter (Wortmann, 2009)

Berdasarkan survei WHO, Indonesia merupakan Negara Terbesar ke-4 di dunia yang penduduknya menderita asam urat, di Indonesia penyakit asam urat $35 \%$ terjadi pada pria diatas usia 34 tahun. Kadar asam urat normal pada pria berkisar 3,5-7 $\mathrm{mg} / \mathrm{dl}$ dan pada perempuan 2,6-6 mg/dl. Kadar asam urat diatas normal di sebut Hiperurisemia. Insiden gout di Indonesia menduduki urutan kedua setelah osteoartritis (Sustrani, 2006). 
Prevalensi penyakit sendi pada usia 55-64 tahun $45,0 \%$, usia $65-74$ tahun 51,9 , usia $\geq 75$ tahun $54,8 \%$. Penyakit sendi yang sering dialami oleh golongan lanjut usia yaitu penyakit artritis gout, osteo arthritis dan artritis reuomatoid. Kebiasaan mengkonsumsi makanan yang mengandung purin $200 \mathrm{mg}$ /hari akan meningkatkan risiko artritis gout tiga kali lebih besar dibandingkan dengan orang yang tidak mengkonsumsi purin (Herliana, 2013).

Tingginya suatu masalah kesehatan sangat erat kaitannya dengan perilaku kesehatan dan perubahan perilaku erat kaitannya dengan pengetahuan seseorang. Nugroho, (2008) menjelaskan bahwa pengetahuan merupakan salah satu faktor predisposisi atau faktor yang mempengaruhi terjadinya perubahan perilaku seseorang. Masalah-masalah kesehatan yang terjadi dalam masyarakat dapat dihindari dengan menerapkan perilaku pencegahan terhadap masalah kesehatan tersebut.

Perilaku pencegahan penyakit merupakan perilaku dimana seseorang melakukan suatu aktivitas untuk menurunkan resiko terjadinya penyakit. Perilaku peningkatan kesehatan dan pencegahan penyakit merupakan bagian dari perilaku sehat yang saling melengkapi satu sama lain untuk memperoleh kesehatan yang optimal. salah satu cara yang dapat kita lakukan adalah dengan memberikan pendidikan kesehatan dan latihan Senam Ergonomik. Senam ergonomik adalah suatu teknik senam untuk mengembalikan atau membetulkan posisi dan kelenturan sistem saraf serta aliran darah, memaksimalkan suplai oksigen ke otak, membuka sistem kecerdasan, keringat, termoregulasi, pembakaran asam urat, kolesterol, gula darah, asam laktat, Kristal oksalat, kesegaran tubuh dan imunitas. Senam ergonomik merupakan senam yang gerakan dasarnya terdiri atas lima gerakan yang masing-masing memiliki manfaat berbeda tetapi saling terkait satu sama lainnya (Wratsongko, 2015).

\section{METODE PELAKSANAAN}

Metode kegiatan program Pengabdian kepada Masyarakat ini terdiri dari tahapan:

a. Penyuluhan /Edukasi

Metode penyuluhan/penyampaian materi dengan menggunakan power point dan handout materi. Meode tanya jawab dilakukan pada saat pemberian materi. Hal ini dilakukan untuk mengetahui respon peserta terhadap materi yang diberikan. Metode evaluasi dilakukan pada awal dan akhir penyampaian materi. Hal ini dilakukan untuk mengetahui tingkat pengetahuan peserta dan perkembangan pengetahuannya setelah pemberian materi

b. Demontsrasi Latihan Senam Ergonomk

Metode demonstrasi dilakukan setelah penyampain materi, tahapan demonstrasi yang dilakukan: sebelumnya trainer melakukan pemanasan terlebih dahulu setelah itu trainer memberikan contoh latihan senam ergonomi yang akan dilakukan lansia, setelah itu trainer meminta pada lansia untuk melakukan Senam Ergonomik sesuai dengan yang dicontohkan oleh trainer.

\section{HASIL DAN PEMBAHASAN}

Dari hasil pengabdian masyarakat yang dilaksanakan di Kelurahan Gaharu Kecamatan Medan Timur terdapat perbedaan yang signifikan 
terhadap kegiatan yang telah dilaksanaan. kegiatan tersebut dapat terlihat dari:

\section{a. Penyuluhan/Edukasi}

Peserta kegiatan penyuluhan ini adalah lansia. Respon dan tingkat partisipasi yang diberikan pada saat penyuluhan ini terlihat dari reaksi peserta yang dapat memahami materi yang disampaikan oleh pemateri sehingga disksui berjalan lancar. Kegiatan penyuluhan ini dapat terukur dengan membagikan kueioner sebelum dan sesudah kegiatan. Dari hasil penyuluhan tersebut terlihat bahwa peningkatan pengetahuan tentang penanganan asam urat. Hasil yang telah dicapai dalam kegiatan pengabdian kepada masyarakat ini berupa peningkatan pengetahuan tentang penanganan asam urat. Hal ini dapat terlihat dari hasil kuesioner yang diambil dari peserta yaitu:

Tabel 1: Kuesioner tentang pemahaman lansia tentang Asam Urat

\begin{tabular}{|l|l|c|c|}
\hline Variabel & Indikator & Jumlah & \% \\
\hline $\begin{array}{l}\text { Penyampai } \\
\text { an materi }\end{array}$ & $\begin{array}{l}\text { Pemahama } \\
\text { n terhadap } \\
\text { materi }\end{array}$ & 21 & 75 \\
\hline $\begin{array}{l}\text { Penangana } \\
\text { n asam } \\
\text { surat }\end{array}$ & $\begin{array}{l}\text { Pemahama } \\
\text { n cara } \\
\text { melakukan } \\
\text { senam } \\
\text { ergonomik }\end{array}$ & 21 & 75 \\
\hline
\end{tabular}

Dari tabel 1. Diatas terlihat bahwa lansia paham dengan materi yang disampaikan dengan persentasi $75 \%$ dan paham dalam penanganan asam urat dengan latihan senam ergonomik dengan persentasi 75\%. Persentase tersebut menunjukkan bahwa lansia sangat antusias dan semangat untuk mengikuti kegiatan pengabdian masyarakat karena meningkatkan pengetahuan dan menguntungkan para lansia karena dapat mengurangi rasa nyeri pada sendi akibat asam urat yang didalaminya.

b. Demontrasi/Latihan Senam Ergonomik

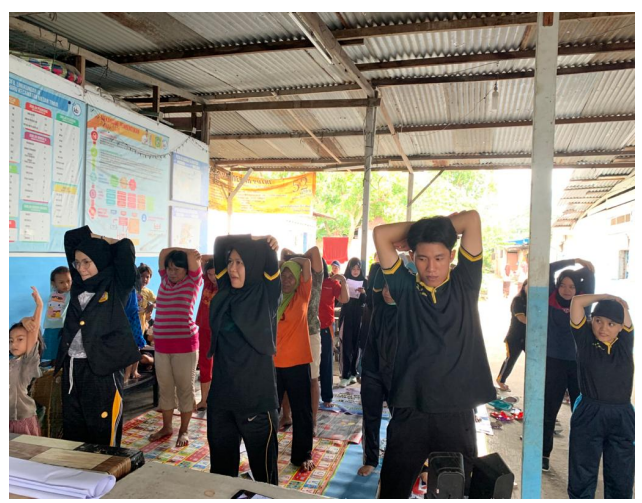

Gambar 1: Gerakan Melapangkan dada

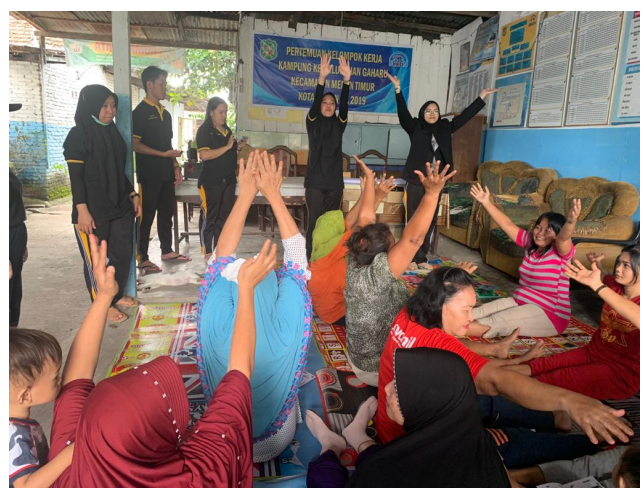

Gambar 2: Gerakan Duduk pembakaran

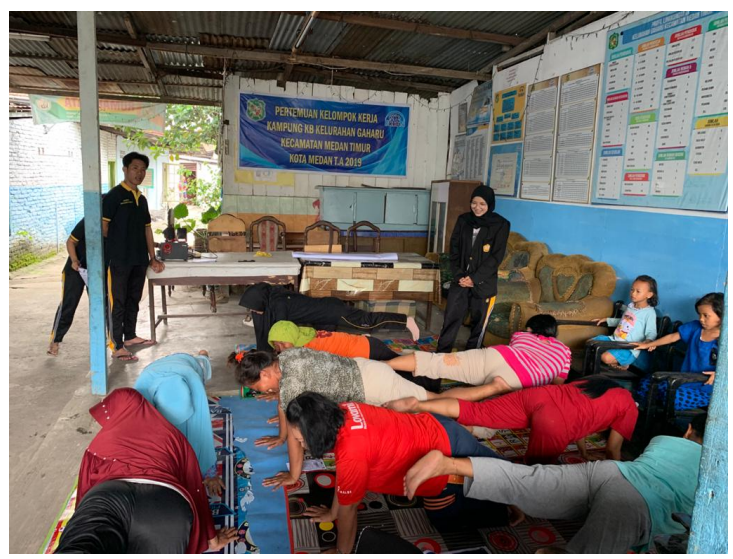

Gambar 3: Gerakan telungkup dengan menegakkan lurus satu kaki kebelakang.

Sebelumnya latihan senam ergonomik pada lansia di kelurahan Gaharu belum pernah dilakukan dan lansia juga baru mendengar jenis latihan ini. 
Pertama sekali peserta masih diberi contoh oleh instruktur karena satupun dari peserta belum mengetahui gerakannya, setelah dilakukan latihan selama 4 kali secara rutin dalam 2 minggu dengan waktu $15-25$ menit $75 \%$ peserta sudah bisa melakukan dengan sendiri tanpa diikuti oleh instruktur.

Senam ergonomis itu sendiri merupakan suatu teknik senam dan pernapasan untuk mengembalikan atau membetulkan posisi dan kelenturan sistem saraf dan aliran darah. Senam ergonomis juga memaksimalkan suplai oksigen ke otak, membuka sistem kecerdasan, sistem keringat, sistem pemanas tubuh, sistem pembakaran (asam urat, kolesterol, gula darah, asam laktat, kristal oxalate), sistem konversi karbohidrat, sistem pembuatan elektrolit dalam darah, sistem kesegaran tubuh dan sistem kekebalan tubuh dari energi negatif/virus, sistem pembuangan energi negatif dari dalam tubuh. Gerakan yang terkandung dalam senam ergonomis merupakan gerakan yang sangat efektif, efisien, dan logis karena rangkaian gerakannya merupakan rangkaian gerakan yang sering dilakukan manusia sejak dulu sampai saat ini (Sagiran. 2012). Tindakan senam ergonomik ini didukung oleh penelitian yang dilakukan Suariana (2014) bahwa senam berpengaruh terhadap perubahan nyeri yang ditimbulkan oleh gout.

\section{KESIMPULAN}

Hasil kegiatan Pengabdian masyarakat ini dapat disimpulkan sebagai beriut:

1. Terdapat perubahan pola pikir lansia terkait asam urat

2. Peningkatan pemahaman lansia tentang latihan senam ergonomik
3. Latihan senam ergonomik ini mendapat sambutan yang baik dari peserta, karena selama 4 kali secara rutin dalam 2 minggu dengan waktu 15-25 menit lansia dapat melakukannya tanpa bantuan $(75 \%)$ meskipun keluarga tetap mendampingi saat latihan dilaksanakan.

\section{REFERENSI}

Herliana. 2013. Penyakit Asam Urat Kandas Berkat Herbal. Jakarta: Fmedia

Nugroho, Wahjudi. 2018. Keperawatan Gerontik dan Geriatric. Jakarta: Buku edokteran EGC.

Sagiran. 2012. Mukjizat Gerakan Sholat. Edisi ke-2. Jakarta: Qultum Media

Suriana, Neti. 2014. Herbal Sakti Atasi Asam Urat. Depok:Mutiara Allamah Utama

Sustrani, L., Alam, S., \& Broto, I. H. 2006. Asam urat. Jakarta: PT. Gramedia Pustaka Utama.

Wortmann RL. 2009. Gout and hyperuricemia. In: Firestein GS, Budd RC, Harris ED,

Wratsongko, Madyo. 2015. Mukjizat Gerakan Sholat. Jakarta Selatan: Mizania

Yenrina, R. 2014. Diet Sehat Untuk Penderita asam urat. Jakarta:Penebar Swadaya 